\title{
The Perspective of Bureaucratic Reform (Kang Yoto's Leadership) in Bojonegoro
}

\section{Fadian Nur Aziz¹, Ali Roziqin²}

1Student of Government Science, University of Muhammadiyah Malang.

Email: fadianna45@gmail.com

${ }^{2}$ Department of Governmental Science, University of Muhammadiyah Malang.

Email: aliroziqin@umm.ac.id

\section{ARTICLE INFO}

Keywords: Bureaucracy Reform, NPS, Rembug

Jumat, Innovation

Kata kunci: Reformasi Birokrasi, NPS, Rembug Jumat, Inovasi

How to cite: Aziz, F. N., Roziqin, A. (2020). The Perspective of Bureaucratic Reform (Kang Yoto's Leadership) in Bojonegoro. JAKPP (Jurnal Analisis Kebijakan dan Pelayanan Publik, 6(2), 126-142.

\section{ABSTRACT}

The short article aims to discuss the bureaucratic reform by Kang Yoto during his leadership in Bojonegoro Regency. In the governance structure, the local government is a street level bureaucracy that must be responsive to community development. Using library analysis and focus group discussions, Authors also discuss with Kang Yoto as directly, when the process of entoring at the University of Muhammadiyah Malang. Authors analyze the bureaucratic reform movement carried out by Kang Yoto able to change people's stigma better towards bureaucracy. Some of the things done by Kang Yoto such as the bloated Friday, transforming public services and bureaucratic innovation succeeded in bringing a positive impact on development in Bojonegoro Regency. Needing this shows the success of bureaucratic reform in the regions needs strong commitment and leadership in the regions. This paper is expected to be able to provoke potential regional leaders who will fight in the simultaneous Regional Election in 2020.

\section{Abstrak}

Artikel singkat ini bertujuan untuk membahas reformasi birokrasi yang dilakukan oleh Kang Yoto selama masa kepemimpinannya di Kabupaten Bojonegoro. Dalam tatanan pemerintahan, pemerintah daerah adalah street level bureaucracy yang harus responsive terhadap perkembangan masyarakat. Menggunakan analisis kepustakaan dan focus group discussion, Penulis juga berdiskusi dengan Kang Yoto secara langsung ketika proses pendampingan di Universitas Muhammadiyah Malang. Penulis menganalisis gerakan reformasi birokrasi yang dilakukan oleh Kang Yoto mampu merubah stigma buruk masyarakat terhadap birokrasi. Adapun beberapa hal yang dilakukan oleh Kang Yoto seperti rembung jum'at, mentransformasi pelayanan publik dan inovasi birokrasi berhasil membawa dampak positif bagi pembangunan di Kabupaten Bojonegoro. Sehingga hal ini menujukkan bahwa keberhasilan reformasi birokrasi di daerah adalah membutuhkan komitmen dan kepemimpinan yang kuat di daerah. Tulisan ini diharapkan mampu memprovokasi para calon pemimpin daerah yang akan bertarung dalam PILKADA serentak 2020. 


\section{Introduction}

Currently, the study of public administration has developed exponentially. Several studies on public administration were heavily focused on poverty, social welfare, bureaucratization and various problems experienced by modern society (Hejiden, 2010; Roziqin \& Yusuf, 2020). Public administration is a strategic factor in economic and social development in a country, including Indonesia. There is also an ongoing departure from the conventional administrative paradigm which places heavy emphasis on state to a community-oriented one (Murtadho \& Roziqin, 2018). To optimize the role of the bureaucracy in society, a bureaucratic institution needs to carry out bureaucratic reform. The purpose of bureaucratic reform is to accelerate the implementation of public services that are accountable, transparent, responsive, and efficient in policy implementation (Haning, 2018). The emergence of New Public Services as a leading paradigm in bureaucratic reform has altered the way scholars or policy-makers approach public administration (Denhardt, 2000). NPS allows greater public participation by presupposing democratic citizenship, community and civil society, and organizational humanism. In addition, in this paradigm, the government is mandated to improve public services rather than directing them.

The concept of NPS then developed in several countries, as a result of globalization. This is no exception in Indonesia, but in Indonesia the types and characteristics of the bureaucracy mostly adhere to the Weberian concept (Dwiyanto, 2011). As commonly understood, the Weberian bureaucracy tends to produce negative outcomes. There are many cases of bureaucratic disease / bureaucratic pathology that have spread, such as poor service, corruption, hierarchy, and rigidity. The inability of the bureaucracy to adapt to its environment is also often blamed for causing bureaucratic pathology (Croizier, 1964).

Furthermore, in this paper the authors take interest in analyzing the development process in the perspective of bureaucratic reform in Bojonegoro Regency. Bojonegoro Regency is known for prodigious oil reserves. However, the problem is in the last few decades the country's economy is at the "Middle Income Trap" level (Kasali, 2017). Middle Income Trap or middle income trap is a state / region economic condition that has succeeded in elevating its economic status from underdeveloped and low-income to middle-income countries / regions (Lumbangaol \& Pasaribu, 2018). This condition also occurs in several areas that are rich in natural resources such as Bojonegoro Regency, which in the case of Bojonegoro Regency, the Government is trying to find a way out of the Middle Income Trap that occurs. However, this condition remains at this level and has no prospects of improving (RPJMD, 2013-2018).

The widespread corruption seems to be an irony in Bojonegoro Regency. Abundant natural resources in the form of oil have caused environmental impacts, conflicts of interest, and corruption (Lauranti, Afrina, Mawesti et al., 2017). However, over time, many people have begun to worry and demand that the local government as the driving force demands a transparent mechanism for government 
administration and the realization of public welfare through improved public services.

The community demands a bureaucratic transformation (Dwiyanto, 2011). Unfortunately, bureaucratic officials at the lower level who have direct access to the community engagement do not have the authority to take discretion, so there is no courage to take the initiative to respond to the problems at hand (Dwiyanto et al., 2002). In addition, local governments need innovation as a step towards creating a more prosperous community. On the other hand, innovative governance is important to the formation of a more just and equal society (Hai et al., 2016). Innovation is needed in government as a key stakeholder that influences the lives of many people.

Optimizing the role of the bureaucracy and improve public services. The Bojonegoro Regency Government under the leadership of Kang Yoto (Suyoto) took strategic steps. Under Kang Yoto's leadership, the first thing that became a concern was efforts to improve governance, in this case bureaucratic reform. There are several things that have been done by the Bojonegoro Regency Government related to bureaucratic reform (NPS) which will be further discussed in this article.

\section{Literature Review}

\section{Bureaucratic Reform}

According to Lubis (2017), the study of bureaucratic reform is a complex study which deals with several aspects related to organization, institutions, human resources, and the system run by the bureaucracy and aspects of bureaucratic reform (Yusriadi \& Misnawati, 2017). So it can be said that the existence of bureaucratic reform as a form of government administrative changes to the form of services to the community in order to improve community welfare. Therefore, Fukuyama (2017) argues that public bureaucracy is a very influential aspect in the scope of state administration that cannot be separated from the context of public services and public affairs (Yusriadi \& Misnawati, 2017).

As the aforementioned description suggests, it is true that bureaucratic reform is related to rearranging the bureaucratic process from the highest to the lowest level and making new breakthroughs (Innovation Breakthrough) by taking gradual steps, concretely, realistically, seriously, thinking outside the existing habitual patterns. (out of the box thinking), and change the direction of the paragdima. Innovation and creative thinking enable government bureaucracy to contribute well in carrying out public administration whose aim is to improve the quality of public services for the satisfaction of the community / citizen, this is in line with the Presidential Regulation of the Republic of Indonesia No. 81/2010 concerning Grand Design of Bureaucratic Reform in 2010-2025

The bureaucratic reform agenda is important for regions because local governments are the lowest bureaucracy (street level bureaucracy) in line with the concepts of autonomy and government decentralization in Indonesia. The 
bureaucratic reform which is contained in the Grand Design of Bureaucratic Reform is concerned with 8 areas of change, including: First, (Organization) creates a bureaucratic organization that can work in accordance with its main tasks and functions and creates a clean, accountable, effective, efficient bureaucracy. and can provide excellent service. Second, (Tatalaksana) changes to the management system are needed in the context of bureaucratic reform to support government administration and public services to improve the quality of the bureaucratic apparatus. Third, laws and regulations which become the basis for the bureaucratic apparatus, so that changes and strengthening of a better statutory system are needed. Fourth, superior Human Resources (HR) is a determining factor for the success of bureaucratic reform, changes in managing HR are things that must be implemented in supporting superior HR management of bureaucratic apparatus. Fifth, supervision of the bureaucratic apparatus must always be carried out to prevent corrupt behavior in the bureaucratic structure, so that preventive supervision is needed. Sixth, accountability in bureaucratic management must undergo changes that encourage bureaucratic apparatus to work better, effectively, and efficiently in carrying out their duties. Seventh, strengthening the public service management system is an indicator to encourage changes in the performance of a more professional bureaucratic apparatus. Eighth, the mindset and culture set of apparatus are part of bureaucratic changes expected to prevent bureaucratic misappropriation.

The commitment and strong political will of local leaders will have a positive impact on the bureaucratic reform agenda in the region. Moreover, presently there are many public mechanisms that can serve as tools for public bureaucracy in the regions as contained in principles of regional governance. From various forms of changes in the bureaucratic reform agenda, it demonstrates that the government bureaucracy must manage government management in accordance with the principles of good and professional governance. In addition, the bureaucracy must be able to answer the demands and problems faced by the community. To ensure that bureaucratic reform can improve the quality and performance of the bureaucratic apparatus to provide public service facilities to the community

\section{New Public Service}

New Public Service (NPS) views society as very important aspect in a democratic government. Government's perspective on society is not only a group's interest (self-interest) but also involves the values, trust and concern among others. Citizens have a position as participants in the government and are able to contribute together to achieve one goal. Therefore, dialogue is needed and involves citizens in gaining common interests (Denhardt \& Denhardt, 2003). Meanwhile, according to (Ningtyas \& Trimurti, 2010) the performance of public organization is contingent on the quality of resources who work within, bureaucrats, thus, in NPS context, play an important roles in ensuring the organization may function in public's best interest. 
New Public Service, in attaining its goals, is guided by several principles, (Denhardt \& Denhardt, 2003) as follows; First, service citizen not consumer, means that in serving the public, the government must really treat the community as citizens, not as customers in the process of providing public services. Second, seek the public interest is a view that prioritizes the public interest and puts aside personal interests to achieve common interests and shared responsibility. Third, value citizenship over entrepreneurship illustrates that the public interest is better run by community institutions than by entrepreneurs where they only care about their own benefits. Fourth, think strategically, act democratically that aims to fulfill public interests can be achieved effectively if they are mutually collective and collaborative. Fifth, recognize that accountability is not simple, meaning that in this perspective government agencies should be more concerned than market mechanisms. In addition, government agencies must comply with laws and regulations, societal values, political norms, professional standards, and the interests of citizens. Sixth, server rather than steer rather refers to the role of government as a leader guided by collectively shared values rather than controlling or directing community toward a new one.

Based on the conceptual imperatives of the New Public Service described above, public services must be responsive in providing services and government as the organizer of the public administrator must involve the community (from the planning, implementation and evaluation processes) in government and other public service tasks. The goal is to create a government that is more responsive and in accordance with basic democratic values.

\section{Research Methods}

This article uses a qualitative approach with a descriptive model. Such approach is used because according to (Creswell \& Creswell, 1994) that "Qualitative research focuses on that process that occurs as well as the product or outcome and to understand a particular social situation, event, role, group, or interaction". Thus, a qualitative approach is considered appropriate for exploring and extracting specific information related to Kang Yoto's leadership in transforming Bojonegoro Regency as a transformative region. This study is limited to the period during which Kang Yoto was the Regent of Bojonegoro Regency (2008-1018).

The data used sourced from the results of the discussion analysis and the class mentoring carried out by Kang Yoto during his teaching in the department of governmental science, University of Muhammadiyah Malang. The author conducted an in-depth interview with Kang Yoto as the key informant to explore the bureaucratic reform strategy in Kab. Bojonegoro. In addition, the author also conducted a focus group discussion related to bureaucratic reform in Bojonegoro Regency with several Government Science students at the University of Muhammadiyah Malang who came from Bojonegoro Regency. There a total of 10 persons serving as key informants. In addition, in analyzing the data, the authors also conducted observation of Kang Yoto's tenure as regent from 2008-2018. 
To cross-check the interview data, the author also collects scientific data through literature studies from journals, books and other relevant scientific sources. The data analysis method is data triangulation (Huberman \& Miles, 2012) which consists of collecting data from both primary and secondary sources, then reducing the data according to the focus of the study; data verification; and data analysis interpreted in a narrative form. Furthermore, this article has no particular interest in practical politics. However, it is purely the result of discussion and an objective view of the bureaucratic reform of Bojonegoro Regency during the tenure of Regent Suyoto (Kang Yoto).

\section{Results and Discussin}

During his time as a regent in Bojonegoro, Suyoto or known as Kang Yoto was able to apply the principles of bureaucratic reform that could change the monotonous bureaucratic culture to a more dynamic direction. This can be seen from how Kang Yoto succeeded in bringing Bojonegoro Regency to being selected as an open government pilot project and being invited to an international discussion forum held abroad, among others: Open Government Partnership Asia Pacific Regional Dialogue 2016 in Manila, 2016 Subnational Pioneers Tier Meeting in Washington DC, the Institute of Development Studies at the University of Sussex Brighton, England in 2016 and the Open Government Partnership Global Summit in December in Paris (Samah, 2017). As well as several other prestigious awards that were received by Bojonegoro Regency. In addition, Kang Yoto's efforts to reposition it as a true community service to be able to establish good communication between the regent and the community and the implication is the welfare of the people of Bojonegoro. The forms of implementation carried out by the Bojonegoro Regent include "Rembug Jumat" (Friday Meeting), Transformation of public services and Government Innovation as a form of improving services to the community and building communication spaces in government administration. As for the practice, Regent Kang Yoto actually presented himself as a public servant. To better understand how Kang Yoto can change Bojonegoro's new face, the following are the explanations.

\section{Rembug Jum'at}

Bojonegoro Regency under the leadership of Suyoto has made many changes. Historically, Bojonegoro was formed from the land of the rising sea. Apart from being barren and can only be planted with teak trees, during the rainy season, the floods do not recede quickly because the soil is alluvial. However, during the flood season, the water is not left in the soil so that the agriculture is not fertile (Khasali, 2017). Therefore, in order to address and discuss what the district government should do, in 2013 the Regent Suyoto took the initiative to open a Malowopati pavilion to the whole community to establish communication. This is based on the importance of community involvement in the decision-making process related to the public interest (Habibah, 2014). 
The Friday Meeting/Public Dialogue according to (Wahyuhono, 2012) is a program of direct meeting between the community and the government in which there is very open access for the public to participate and openly submit complaints in front of the Regent and Deputy Regent as well as other local government officials. This dialogue serves as a platform for young and old generations to think about and discuss the future of Bojonegoro. This forum is held every Friday starting at 13.00 WIB until finished (Habibah, 2014). This program has received high enthusiasm from the community, as indicated by the following table:

Table 1. Proportion of Questions and

Information in the Friday Dialogue in

Bojonegoro Regency, 2013

\begin{tabular}{clcc}
\hline NO & \multicolumn{1}{c}{ Topic } & Numbers & $\%$ \\
\hline 1 & Government & 82 & $18 \%$ \\
2 & Social Issues & 72 & $15 \%$ \\
3 & Education & 58 & $12 \%$ \\
4 & Public Works & 54 & $11 \%$ \\
5 & Agriculture, Fisheries, Animal & 71 & $15 \%$ \\
6 & Husbandry and Forestry & 39 & $8 \%$ \\
7 & Transportation & 35 & $7 \%$ \\
8 & Irrigation & 34 & $7 \%$ \\
9 & Health & 31 & $7 \%$ \\
\hline
\end{tabular}

Source: retrieved from (Habibah, 2014)

Rembug Jumat held as a form of deliberative communication to find solutions to collectively shared problems and serve as community's source of information related to public policy. Over time, the attention or consistency of the Bojonegoro Regency government continues to increase with the assistance of the regional work unit (SKPD) as an actor in realizing policies and also assisted by stakeholders such as academics, businessmen and communities in the Bojonegoro Regency (Diskominfo, 2017). The implementation of activities really reflects what is the main problem in the community. So that the community is not only the recipients of but is always involved in every decision making. This means that community participation contributes to the district government in designing public policies and services.

At same point, the apparatus in Bojonegoro Regency agree with the initiative mainly due to the capacity of the apparatus. 
"Several notes on when I tried to overhaul the bureaucratic conditions in the District. At the beginning of my administration, Bojonegoro was a bit tough indeed. Because apart from being a new leader struggling to make the government transition successful. I also had to fight against the bureaucratic elements that went against some of the strategies I implemented" (Interview with Kang Yoto, March 16, 2020)

The bureaucratic condition that got in the way of government's strategy was the limited capacity of ASN (public servants). ASN, mainly the older ones, were not well equipped to contribute to Kang Yoto's innovative and transformative agenda. Whereas the competence and professionalism of apparatus in bureaucracy is nonnegotiable (Mubin \& Roziqin, 2018). It brings to attention that the key to the success of bureaucratic reform is determined by the quality of human resources

Rembug Jumat is a form of transparency and community involvement in the policy-making process. Not only that, the principle of NPS is actually applied in this program, which places the community as the receiving subject, not only as an object of policy or program (citizenship oriented). In addition, Rembug Jumat will increase the transparency of local government management. The open access to transparency makes Bojonegoro Regency able to apply open government, and builds closeness between the government and the community, and makes community problems a government problem.

Although at first it was difficult to apply the principles of open government. Through this Friday dialogue, the public will increasingly know what are the obstacles for local governments in developing their regions.

"Every Friday, after Friday prayers, the residents flock to the Friday dialogue. They are very enthusiastic about the development process in Bojonegoro Regency. So this indirectly fosters a sense of belonging and mutual cooperation". (Interview with Kang Yoto, March 16, 2020).

An active democratic life through Rembug Jumat is an important element in the NPS. This was confirmed in a small discussion conducted by the author with several students of Government Science in Bojonegoro Regency, that Friday's dialogue became a medium for complaining, as well as a forum for the community to provide suggestions and constructive criticism to local governments openly. In fact, openness through the Friday dialogue has succeeded in attracting world organizations to learn from the implementation of open government in Bojonegoro Regency (see Geraldy \& Musrifah, 2017). Based on the results of the interview with Kang Yoto, holding this inter-community dialogue is an application of democratic value that has to be perpetually in place in order to meet the needs of society and ensure the welfare of society. The dialogues consist of complaints and questions regarding government's agenda.

"The majority of discussion materials were questions about problems, programs, and what the local government would do about problems in the community" (Interview with Suyoto, 10 March 2020). 
Table 2. Category of Community Aspirations in the Friday Dialogue in Bojonegoro Regency in 2014

\begin{tabular}{lc}
\multicolumn{1}{c}{ Aspiration } & Percentage \\
\hline Proposals/Critics & $27 \%$ \\
Questions & $30 \%$ \\
Testimonials & $8 \%$ \\
$\begin{array}{l}\text { Application for physical } \\
\text { buildings }\end{array}$ & $28 \%$ \\
Complaints & $7 \%$ \\
\multicolumn{2}{c}{ Total } \\
& Source: retrieved from (Habibah, 2014)
\end{tabular}

As for some examples of public policies that are the result of community involvement in public dialogue (Habibah, 2014) are the farmer planting pattern policy, construction of forest roads, control of street vendors, policies intended for beneficiary families (Rastra) Perbup number 18 of 2012 concerning the Water User Farmer Association. Further, Bouckaert et al., (2002); Heintzman \& Marson (2005) in (Wahyuhono, 2012) made two arguments regarding the form of government performance that must be carried out first, macro-performance, namely the central role of government in providing general public services such as economic growth, employment, health insurance, education and environmental health. Second, namely micro-performance, which emphasizes more on bureaucratic and administrative performance technically, especially the role of the government in improving quality public services.

\section{Public Service Transformation}

After the succe ss of the public dialogue program, the Bojonegoro Regency Government made efforts to improve public services. As stated by Kang Yoto, "Innovation is a result, Reform is the way, and the best service is the spirit" (Interview with Suyoto, 10 March 2020). This means that all government affairs related to public services must be oriented to the community and provide the best service. One of them is providing an innovation by using technological means in the process of public services or also known as E-government by digitizing public services and information related to government activities.

One of the forms of public service transformation promoted by Kang Yoto is short message service (SMS) network that is directly connected to Kang Yoto's telephone number. Based on the results of the interview with him, he stated that almost every day messages from the public came in with lots of complaints related to public service, education and health. However, not a few also expressed hate speech against Kang Yoto's leadership (Interview with Suyoto, 10 March 2020). Public complaints can also be submitted through the SIAP LAPOR application, which is useful as an integration system to facilitate complaints and aspiration managed by the Bojonegoro Regency SKPD to build public trust. As for some of 
these websites, among others: www.lapor.go.id, and www.bojonegorokab.go.id can be directly accessed by the people of Bojonegoro. In addition, since 2013 the Bojonegoro government has implemented the Population Administration Services Integrated Program (PATEN). There are 74 district authorities delegated to sub-districts. Some of these programs and applications are a form of commitment by the District Government to apply the principles of transparency, accountability, participation and innovation in accordance with the emphasis of the concept New Public Services.

The initiatives by district government have been applauded nationally and even international. Bureaucratic reform, in this case innovation by promoting open government, becomes the driving force behind Bojonegoro's success in providing space for public participation and improving public service delivery (Hadi, Asworo, \& Taqwa, 2020). As a result, slowly public trust in the bureaucracy and the community satisfaction index has increased (see Suryo, 2019; Haryanti, 2016), and it has an impact on the human development index of Bojonegoro Regency which also increases.

\section{Table 3. Human Development Index Graph for Bojonegoro Regency in 2018}

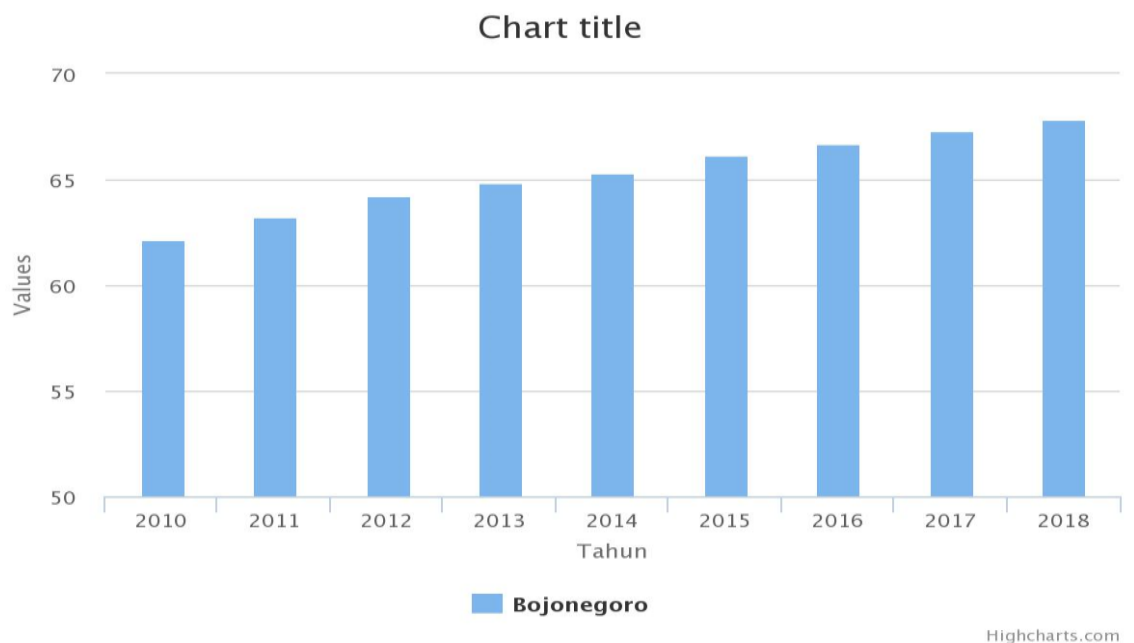

Source: Central Bureau of Statistics, 2018

Indicated by Human Development Index (HDI) data above, starting in 2013 the HDI achievement of Bojonegoro Regency was $64,85 \%$ and increased by $1.58 \%$ in 2014 amounted to $65.27 \%$. Subsequently, Bojonegoro IPM continued to increase in 2015 by $66.17 \%$ and in 2016 by $66.73 \%$ and at the end of Kang Yoto's leadership in 2018 IPM Bojonegoro peaked at $67.85 \%$. This is an extraordinary achievement that originates from leadership's willingness to engage the community. Kang Yoto successfully implemented innovation in understanding and responding quickly to the demands of the Bojonegoro community.

The transformation of governance carried out by Bojonegoro Regency belongs to the NPS approach framework. In the NPS model, consistency of 
democratic citizenship and civil society is the main aspect of public service. This means that the community is not only used as voters, clients, or customers but also controls and powers in determining the direction of public policy (collaboration) (Denhardt, 2000). According to (Perry, 2007) there are 7 things that should be given much thought in NPS: "serve citizens not customers, seek the public interest, value citizenship over entrepreneurship, think strategically, act democratically, recognize that accountability is not simple, serve rather than steer, value people not just productivity". Some of these things are certainly synonymous with several existing programs in Bojonegoro Regency, especially those related to serving the community not as customers, seeking public interests, and thinking strategically and acting democratically as proven in Rembug Jumat and the innovation of the SIAP LAPOR application. This means that Kang Yoto and SKPD in the Bojonegoro Regency government understand that building public dialogue, direct SMS, and the SIAP LAPOR application is a form of democratic steps in the midst of the interests of the political elite.

\section{Innovation}

Understanding the diversity of public problems requires a shift in governing paradigm. A government must depart from symbolistic approach to a more community-engaging one. There must be a concrete form of public problems exploration (Geraldy \& Musrifah, 2017). Kang Yoto understood that governing mechanism must go hand in hand with innovation as key to creating an innovative and accountable government. Innovation serves the purpose of problem solving (IDEO, 2016). In this millennial era, the government needs an innovation to maintain its existence as well as modify public services to be better and more just. This is of course a response to New Public Management (NPM) paradigm which tends to place people as customers and prioritize privatization of public services (Osborne et al., 2013) An excellent public service will bring a region closer to its goal and indeed receive support from all relevant stakeholders.

However, not all programs related to bureaucratic reform in Bojongeoro Regency have been running optimally. There are only obstacles faced in making a change. The obstacles faced are mainly community mindset, according to (Khasali, 2017) there are six mindsets that we need to avoid as a nation.

1. Taking life for granted

2. Running away from responsibility

3. Process-averse

4. Jealousy

5. Believing in hearsay as a source of truth

6. Beggar mentality

As an oil-producing area, and rich in natural resources, there are anomalies such as the condition of small communities who are still living under poverty as a result of the improper management system of the local government. This is as stated 
by Schumacher (1973) in the book small is beautiful that there has been an imbalance in social welfare due to the exploitation of natural resources and the implication is that the small community has. This view differs from the opinion that views natural wealth as a resource that must be protected, seen as sustainable and also inherited (Khasali, 2017). If people's mindset regarding natural resource is not changed, then people will be reluctant to improve themselves and will continuously rely on these natural resources. In addition, because the majority of the Bojonegoro area is an agricultural area, the people are mostly farmers (Rustinsyah, 2015). Vast majority of them are unable to use and have an access to digital technology which renders egovernment difficult to implement.

In agricultural society, human resources quality tend to be inadequate as people are predominantly illiterate (Rusinsyah, 2015). Therefore, to face the condition of society with such negative culture, government must improve the quality of human resources, prepare the infrastructure for supporting the use of information technology or e-readiness to realize excellent service. This is of course in accordance with the vision and mission and strategic plans that have been set out in the RPJMD of Bojonegoro Regency. By providing equal access to education and health, it is hoped that the quality of human resources and community competence will increase.

\section{The synergy between government agencies.}

Kang Yoto's bureaucratic reform agenda was focused on building effective communication in governance through a long process. One of the processes is openness or open government which is carried out through public dialogue to look for public problems such as poverty, education, infrastructure and corruption (Suyoto, 2016). This form of communication aims to build synergy. The synergy between government agencies will have an impact on the coordination space to achieve the goals of the programs it carries out (Rahmawati, Noor, \& Wanusmawatie, 2014). Through the synergy between government agencies or institutions, it is hoped that they will be able to answer the challenges faced by reforming the system. This is important because in many local government practices, sectoral or service egos are very high, so that synergy is a fundamental effort to jointly achieve government goals.

One form of synergy carried out by the Bojonegoro Regency government is when Bojonegoro tries to collaborate with stakeholders, namely academics, business and the community in reviewing policy programs. One of them is the public dialogue that has been described above. The success of the Bojonegoro Regency government singergitas has brought a big influence, especially in the principle of open government, so that it attracted the attention of the Organization for Economic Cooperation of Development (OECD). Accompanied by the National Development Planning Agency (Bappenas), Bojonegoro stepped forward as one of the pilot projects for the open government partnership representing Indonesia from 15 world regional governments in the open government in 2016 and became a presenter in international forums, one of which was the Open Government Partnership Asia Pacific Regional Dialogue this year. 2016 in Manila. Thus, to make 
thesuccess, Open Government Partnership (OGP) athe Bojonegoro government synergizes all Regional Work Units (SKPD) to prepare themselves in technical matters to the legal foundation in implementing e-Government (Lauranti, Afrina, Mawesti et al, 2017). In preparing supporting facilities, the SKPD involved, among others, the Community and Government Empowerment Service (DPMD) together with the Ministry of Communication and Information, Bappeda, BPKAD, and Civil Society Organization (CSO) cooperate or synergize in designing a village government transparency index. The following is the stage data presented by (Lauranti, Afrina, Mawesti, \& et, 2017) which were run in the first year:

1. Transparency (40\%): Type of Information Publication, Media information, rules of procedure for village information

2. Accountability (20\%): Planning, socialization, and the level of community satisfaction

3. Participation (25\%): community involvement, development activities and evaluation

4. Innovation (15\%): Media based on ICT (Information and Communication Technology).

Based on the data above, it can be seen that the Bojonegoro government has successfully implemented one of the road maps of bureaucratic reform which has created synergy between government agencies and coordinated with each other to achieve a common goal. Through these 4 basic principles, between agencies, both government and non-government, jointly build a commitment to realizing an effective and efficient government with good communication between stakeholders. Thus, it can be said that bureaucratic reform is a structured mechanism and innovation is one way to improve good public services.

Synergy through collaboration between stakeholders can provide the same understanding between government agencies in order to change the responsive and serving conditions of the bureaucracy. Public services that are responsive to problems are clear evidence of New Public Services, the government bureaucracy must have service-oriented principles

\section{Conclusion}

The perspective of bureaucratic reform carried out in Bojenogoro Regency is one of the actions to improve the quality of bureaucratic performance, because problems that occur in the public bureaucratic structure are numerous and arguably complex. With the development of the public administration paradigm, the reference to public administration no longer rests on economic and social issues, but includes common interests. Emerging of bureaucratic reform as an impetus for the New Public Service paradigm in providing an important role for the bureaucratic apparatus to create an effective, efficient, accountable, transparent, and responsive bureaucracy in providing public services. 
The breakthroughs made by Bojonegoro Regency need to get appreciation and need to be modified by other regions in order to improve public services. The existence of innovation, transformation and reform in the bureaucracy aims to change the stigma of society about the bureaucracy and improve public services in a just manner. Moreover, by approaching the simultaneous regional elections in 2020, there will be many regional head candidates who promote themselves to become regional leaders. The community must be careful which leaders are egalitarian and committed to improving the local bureaucratic system. Because through a competent bureaucracy, regional progress is expected to continue to increase. This is a step towards realizing a "world class bureaucracy", so that the dream of Indonesia Gold 2045 will be realized.

\section{Suggestion}

The purpose of bureaucratic reform can be realized or not depending on how local governments can actually implement the Grand Design of Bureaucratic Reform as a nation's ideal. The existence of bureaucratic reform is none other than to improve justice and public welfare. The bureaucratic reform agenda in the regional scope is important in the future. It takes commitment and strong political will to improve the bureaucratic conditions in the regions. Nevertheless, the experience from Bojonegoro District proves that a strong commitment from the leader can be an important element in the success of bureaucratic reform. However, there is something even more important about a government system that is clean, open, responsive and serving. So that no matter how often regional leaders change, the bureaucratic reform agenda remains one direction and a vision on an ongoing basis.

Through the political will and awareness of wanting to change by local government officials in improving the bureaucracy, the success of bureaucratic reform is not a utopian thing. In addition, public awareness efforts to be actively involved and participate are also very necessary. Because society is not only the object of program or policy targets, but also as the subject. So that the role of the community will further help the government identify the problems they face. The active participation of the community and the openness of the government will be important assets to create a bureaucracy that serves and makes the community prosperous.

\section{References}

Bouckaert Geert, Van de Walle Steven, Maddens Bart \& Kampen Jarl K. (2002). Identity vs Performance: An Overview of Theories Explaining Trust in Government' (Second Report Citizen Directed Governance: Quality and Trust in Government'). Public Management Institute, Katholike Universiteit Leuven.

Creswell, J. W., \& Creswell, D. J. (1994). Research Design: Qualitative, Quantitative, and Mixed Methods Approaches. Carlifornia: Sage Publication

Croizier, M. (1964). The Bureaucratic Phenomenan. Chicago: Chicago University Press. 
Denhardt, J. V., \& Denhanrdt, R, B. (2003). The New Public Service: Serving, not Steering,. New York: M.E.Shape.

Denhardt, R. B. (2000). The New Public Services:Serving Rather than Steering. Public Administration Review , 549-559.

Dwiyanto, Agus. (2002). Reformasi Birokrasi Publik di Indonesia. Yogyakarta: Galang Prentika.

Dwiyanto, A. (2011). Mengembalikan Kepercayaan Publik Melalui Reformasi Birokrasi. Jakarta: Gramedia Pustaka Utama.

Fukuyama, F. (2017). State building: Governance and world order in the 21st century.

Galang Geraldy, \& Sri Musrifah. (2017). Proyek Ogp Bojonegoro: Studi Analisa Paradigma Manajemen Pemerintahan Dalam Proyek Open Government Partnership Di Kabupaten Bojonegoro. Prosiding SNasPPM, 2(1), 95-100.

Habibah, B. A. (2014). Efektivitas Dialog Jum'at Sebagai Model Pembuatan Kebijakan Publik Deliberatif di Kabupaten Bojonegoro. Jurnal Imu Administrasi Negara UNAIR .

Hadi, K., Asworo, L., \& Taqwa, I. S. (2020). Inovasi Dialogis: MenujuTransformasi Pelayanan Publik Yang Partisipatif (Kajian Sistem Pelayanan Malang Online). Journal of Government and Civil Society, 4 (1), 115-129.

Hai, D. P., Roig-Dobón, S., \& Sánchez-García, J. L. (2016). Innovative governance from public policy unities. Journal of Business Research. https://doi.org/10.1016/j.jbusres.2015.10.135

Haning, M.T. (2018). Reformasi Birokrasi di Indonesia: Tinjauan Dari Perspektif Administrasi Publik. JAKPP (Jurnal Analisis Kebijakan dan Pelayanan Publik), 4(1), 25-37.

Haryanti, E. (2016) 'Survei Indeks Kepuasan Masyarakat Kabupaten Bojonegoro', Jurnal Ilmiah Sosio Agribis, 16(2), pp. 64-79. doi: 10.30742/jisa.v16i2.376

Heintzman \& Marson, R. \&. (2005). People, service and trust: is there a public sector service value? International Review of Administrative Sciences , 549-575.

Hejiden, M. v. (2010). Introduction: New Perspectives on Public Services in Early Modern Europe. Journal of Urban Society , 271-284.

Huberman, A., \& Miles, M. (2012). Understanding and Validity in Qualitative Research. In The Qualitative Researcher's Companion. https:// doi.org/10.4135/9781412986274.n2

IDEO. (2016). Innovation in Government. Washington DC: ourpublicservice.org.

Kabupaten Bojonegoro. (2013-2018). RPJMD. Bojonegoro.

Khasali, R. (2017). Disruption. Jakarta: Gramedia Pustaka Utama. 
Lauranti, M., Djamhari, E.A., Mawesti, D. (2017). Mengkaji Penggunaan eGovernment Pemerintah Daerah di Indonesia. (pp. 1-121). Jakarta: Perkumpulan Arkarsa.

Lubis, H. (2017). Penyediaan Pelayanan Publik Dalam Persoalan Sampah Di Kota Pekanbaru Tahun 2014-2016. Jurnal Online Mahasiswa (JOM) Bidang Ilmu Sosial dan Ilmu Politik , 4 (2), 1-15.

Lumbangaol, H. E., \& Pasaribu, E. (2018). Existence and Determinants of Middle Income Trap in Indonesia. Jurnal Ekonomi \& Kebijakan Publik, 9 (2), 83-97.

Mubin, F., \& Roziqin, A. (2018). Meritocracy of Bureaucracy in Indonesia. International Journal of Social Science and Humanity, 8(8), 241-246. https://doi.org/10.18178/ijssh.2018.v8.968.

Murtadho, I., \& Rozqin, A. (2018). 26. Public Governance Perspective To Adressing Development Problems in Surabaya City. 241(IcoSaPS), 109-114. https://doi.org/10.2991/icosaps-18.2018.26.

Ningtyas, \& Trimurti. (2010). Pengaruh Kompensasi Finansial Terhadap Kinerja Manajerial dengan Komitmen Organisasi sebagai Variabel intervening di Direktorat Jendral Pajak (DJP) Wilayah Jawa Timur I. Skripsi.

Osborne, S. P., Radnor, Z., \& Nasi, G. (2013). A New Theory for Public Service Management? Toward a (Public) Service-Dominant Approach. American Review of Public Administration. https:/ / doi.org/10.1177/0275074012466935

Perry, J. L. (2007). Democracy and The New Public Services. The American Review of Public Administration , 3-16.

Rahmawati, T., Noor, I., \& Wanusmawatie, I. (2014). Sinergitas Stakeholders Dalam Inovasi Daerah (Studi pada Program Seminggu di Kota Probolinggo (SEMIPRO). Jurnal Administrasi Publik FIA Brawijaya , 2 (4), 641-647.

Roziqin, A., \& Yusuf, I. M. (2020). Implementasi Kebijakan Beasiswa Bidikmisi: Studi Kasus di Universitas Diponegoro (2018). Publik (Jurnal Ilmu Administrasi). https:// doi.org/10.31314/pjia.8.2.110-122.2019

Rustinsyah. (2015). Social Capital and Implementation of Subsidized Fertilizer Programme for Small Farmers: A Case Study in Rural Java, Indonesia. International Journal of Rural Management , 25-39. https://doi.org/10.1177/0973005215572730

Samah, K. (2017). Belaian si Embok: Kang Yoto Membawa Bojonegoro ke Pentas Dunia. Jakarta: Gramedia Pustaka Utama.

Suryo, B. (2019). Pelayanan Publik dan Pelayanan Kesehatan yang Baik, Diawali dari Perkara Kecil. Retrieved June 16, 2020, from https:/ /jurnaba.co/pelayanan-publik-dan-pelayanan-kesehatan-yang-baikdiawali-dari-perkara-kecil/ (accessed on 4 May 2020)

Wahyuhono, D. (2012). Kajian Trust Pada Program Dialog Publik Kabupaten Bojonegoro. Jurnal Politik dan Manajemen Politik , 33-64. 
JAKPP (Jurnal Analisis Kebijakan dan Pelayanan Publik)

6(2), 126-142: The Perspective of Bureaucratic Reform...

Yusriadi, \& Misnawati. (2017). Reformasi Birokrasi Dalam Pelayanan Publik (Studi Pelayanan Terpadu Satu Pintu). Jurnal Ilmiah Ilmu Administrasi Publik , 7 (2), 99-108. https://doi.org/10.26858/jiap.v7i2.4954 